\title{
Sosial Budaya, Koping dan Dukungan Sosial terhadap Kecemasan Remaja Kelas VII di SMPN 276
}

\author{
Uci Ciptiasrini, ${ }^{1}$ Andiana Kanendyah Putri ${ }^{2}$ \\ ${ }^{1,2}$ Program Studi Kebidanan Program Sarjana Terapan Sekolah Tinggi Ilmu Kesehatan Indonesia Maju \\ Jln. Harapan Nomor 50, Lenteng Agung - Jakarta Selatan 12610, Indonesia \\ Telp : (021) 78894045 Email :, uci.ciptiasrini@stikim.ac.id ${ }^{1}$, andiana_kp@yahoo.com²
}

\begin{abstract}
Abstrak
Remaja yakni masa transisi dari kanak-kanak menuju dewasa dimana terjadi perkembangan dan perubahan yang sangat pesat.Tujuan penelitian untuk mengetahui hubungan sosial budaya, respon koping dan dukungan sosial terhadap tingkat kecemasan remaja awal pada perkembangan seksualitas kelas VII di SMPN 276 Jakarta tahun 2018. Jenis penelitian kuantitatif, desain deskriptif analitik menggunakan pendekatan cross sectional. Jumlah populasi 216 responden dan sampel 140 responden dengan teknik random sampling menggunakan kuesioner. Analisis data dengan univariat dan bivariat menggunakan uji chi square. Hasil univariat didapatkan 50 orang $(35,7 \%)$ memiliki tingkat kecemasan sedang, 80 orang $(57,1 \%)$ memiliki sosial budaya yang buruk, 76 orang $(54,3 \%)$ memiliki koping maladaptif, 85 orang $(60,7 \%)$ memiliki dukungan sosial rendah. Hasil bivariat menunjukkan sosial budaya $(\mathrm{P}$ value $=0,009)$, respon koping $(\mathrm{P}$ value $=0,007)$, dukungan sosial $(\mathrm{P}$ value $=$ 0,014) memiliki hubungan dengan tingkat kecemasan remaja awal pada perkembangan seksualitas. Dapat disimpulkan terdapat hubungan sosial budaya, respon koping dan dukungan sosial terhadap tingkat kecemasan remaja awal pada perkembangan seksualitas. Diharapkan remaja memahami informasi tentang perkembangan seksualitas pada remaja sehingga siap menghadapi perkembangan seksualitas tersebut.
\end{abstract}

Kata kunci : Kecemasan, Sosial Budaya, Koping, Dukungan

\begin{abstract}
Adolescence is a transition from childhood to adulthood where there is rapid development and changes. The objectives of the research were to find out the correlation between Socio-Cultural, Coping Response And Social Support Against Early Adolescence Anxiety Level On Development Of Sexuality Class VII At SMPN 276 Jakarta 2018. Quantitative research type, descriptive analytic design using cross sectional approach. Total population 216 respondents and 140 samples of respondents with random sampling technique using questionnaires. Data analysis was done univariat and bivariate using chi square test. The univariate result was found that 50 people $(35,7 \%)$ had moderate anxiety level, 80 people $(57,1 \%)$ had bad social culture, 76 people (54,3\%) had maladaptive coping response, 85 people $(60,7 \%)$ have low social support. The result of bivariate shows socioculture $(P$ value $=0,009)$, coping response $(P$ value $=0,007)$, social support $(P$ value $=0,014)$ has correlation with early adolescent anxiety level on development of sexuality. Can be concluded there are social-cultural relations, coping responses and social support to early adolescent anxiety level on the development of sexuality. It is expected teenagers understand information about the development of sexuality in adolescents so ready in the face of the development of sexuality.
\end{abstract}

Keywords : Anxiety, Socio-Culture, Coping, Support 


\section{Pendahuluan}

Remaja adalah tahapan seseorang dalam mengalami pubertas dimana terjadi transisi dari masa anak-anak ke masa remaja. Rentang usianya dari 10-19 tahun. ${ }^{1}$ Remaja yang berusia 10-19 tahun ada sekiranya seperlima dari populasi penduduk dunia juga sekitar 900 juta berada di negara berkembang. Diperkirakan populasi remaja di dunia berkisar 1,2 milyar atau $18 \%$ dari populasi penduduk di dunia. ${ }^{2}$

Menurut Dinas Kesehatan RI, tahap perkembangan remaja dikelompokkan atas 3 tahapan yakni: remaja awal (10-14 tahun), remaja tengah (15-16 tahun) dan remaja akhir (17-19 tahun). ${ }^{3}$ Berdasarkan laporan dari Badan Pusat Statistik (BPS) Tahun 2010 membuktikan bahwa penduduk Indonesia berjumlah 237,6 juta jiwa dan 63,4 juta diantaranya merupakan remaja, yang terbagi atas laki-laki berjumlah 32.164 .436 jiwa $(50,70 \%)$ dan perempuan berjumlah 31.279 .012 jiwa $(49,30 \%){ }^{4}$

Tingginya populasi remaja dapat meningkatkan permasalahan yang akan dijumpai oleh remaja berhubungan dengan masa tumbuh kembangnya. SDKI-R tahun 2012 menjelaskan bahwa perubahan fisik yang dialami remaja laki-laki paling sering disebutkan oleh responden wanita adalah perubahan suara $(69 \%)$, sedangkan perubahan fisik yang dialami remaja laki-laki dan paling sering disebutkan oleh responden pria yakni pertumbuhan rambut pada wajah, dada, sekitar alat kelamin, ketiak, lengan atau kaki (50\%). Perubahan fisik pada remaja lakilaki yang jarang disebutkan yaitu puting susu mengeras. Pada remaja perempuan, perubahan fisik yang sering disebutkan oleh responden wanita adalah mulai mengalami haid (83\%), lalu pertumbuhan payudara (73\%). Responden pria mempunyai pola sebaliknya, mereka lebih cenderung menyebutkan pertumbuhan payudara $(58 \%)$, lalu diikuti dengan mulainya haid (43\%). Hanya sedikit responden yang menjelaskan peningkatan gairah seks yakni salah satu tanda perubahan fisik yang dialami oleh remaja perempuan (3\% oleh pria dan $4 \%$ oleh wanita) maupun laki-laki (4\% pada wanita dan $6 \%$ pada pria). ${ }^{4}$

Hormon pubertas menyebabkan adanya peningkatan gairah seks yang dialami remaja yang memberi efek pada perubahan sikap dan pola pemikiran remaja. Data hasil SDKI-R 2012 membuktikan bahwa sebanyak 29,5\% remaja laki-laki dan $6,2 \%$ remaja perempuan pernah merangsang atau meraba pasangannya dan pernah berciuman bibir sebanyak $48,1 \%$ remaja laki-laki dan 29,3\% remaja perempuan. Dalam survei tersebut dibuktikan juga bahwa usia berpacaran untuk yang pertama kali paling banyak diusia 15-17 tahun, yaitu pada $45,3 \%$ remaja laki-laki dan $47 \%$ remaja perempuan. Dari keseluruhan responden yang berusia 10-24 tahun, hanya $14,8 \%$ yang mengatakan bahwa belum pernah berpacaran sama sekali. ${ }^{4}$

Masa remaja yakni masa transisi yang terkandung perubahan yang terjadi pada dirinya. Masa remaja atau masa pubertas yaitu suatu masa peralihan dari anak-anak menuju dewasa yang banyak menjumpai perubahan baik secara fisik, psikologis juga sosial. Pada saat remaja terjadi perkembangan dinamis pada kehidupan seseorang yang ditandai oleh percepatan pertumbuhan fisik, sosial juga emosional. Perubahan fisik yang berlangsung diantaranya adamya proses pematangan organ reproduksi serta juga sudah terjadi perubahan psikologis. Hal tersebut menghasilkan perubahan sikap juga tingkah laku contohnya mulai memperhatikan penampilan diri, mulai tertarik kepada lawan jenis, berusaha menarik perhatian dan muncul perasaan cinta lalu akan timbul dorongan seksual. Karena masa remaja cenderung memiliki tingkat seksual yang tinggi selaras dengan mulai matangnya hormon seksual dan organ reproduksi. Saat usia remaja organ reproduksi sensitif pada infeksi pada saluran reproduksi, kehamilan, dan penggunaan obat-obatan. ${ }^{2}$

Masa transisi dari masa anak menuju dewasa, terjadi pacu tumbuh (growth spurt), muncul tanda-tanda seks sekunder, tercapainya fertilitas serta timbul perubahan psikologik juga kognitif. Dengan demikian biasa disebut dengan fase mencari jati diri. Remaja masih belum bisa untuk menguasai dan memanfaatkan secara maksimal fungsi fisik ataupun psikisnya. Namun yang perlu diingatkan disini bahwa fase remaja adalah fase perkembangan yang tengah berada pada masa sangat potensial, dapat diperhatikan dari segi fisik, kognitif, maupun emosi. ${ }^{5}$

Seksualitas pada masa remaja ditandai dengan terjalinnya interaksi antar lawan jenis, 
yaitu berkencan. Dalam berkencan dengan pasangannya, remaja mengekspresikannya dengan berbagai cara, contohnya seperti memberikan bunga, tanda mata, mengirim surat, bergandengan tangan, berciuman dan sebagainya. Adanya dorongan seksual serta rasa ketertarikan pada lawan jenisnya, sehingga terdapat remaja yang secara terbuka melakukan percobaan pada kehidupan seksual. $^{6}$

Perubahan yang dirasakan pada remaja akan membuatnya memperoleh peran baru serta terpaku pada kegiatan baru, sehingga dapat menyebabkan kecemasan. ${ }^{7}$ Kecemasan yakni kondisi khawatir ataupun gelisah yang tidak pasti juga reaksi ketakutan dengan keluhan fisiologis. Kecemasan yakni kondisi individu merasakan perasaan yang tidak menyenangkan diikuti dengan perubahan fisik yang menambah perasaan tidak menyenangkan. Kondisi tersebut sering dan sulit menunjuk dengan tepat, tapi kecemasan tersebut selalu dirasakan. ${ }^{8}$

Studi pendahuluan yang dilaksanakan di SMPN 276 Jakarta pada 10 orang siswa, didapatkan bahwa 7 siswa tidak mengetahui mengenai perkembangan seksualitas remaja serta mengalami kecemasan dalam menghadapi perkembangan seksualitas 3 siswa lainnya mengetahui mengenai perkembangan seksualitas remaja serta menganggap perkembangan seksualitas tidak perlu dicemaskan sebab perkembangan seksualitas yakni proses yang pasti akan dialami dan dirasakan oleh setiap manusia terutama remaja. 2 dari 7 siswa mempunyai sosial budaya yang buruk dalam menghadapi perkembangan seksualitas remaja karena mereka masih meyakini kebiasaan atau tradisi yang diwariskan secara turun menurun. 3 dari 7 siswa mempunyai respon koping yang negatif terhadap perkembangan seksualitas remaja sehingga mereka belum bisa mengatasi situasi yang tidak menyenangkan atau perubahan yang dihadapi atau beban yang diterima tubuh. Sebanyak 2 dari 7 siswa tidak mendapatkan dukungan sosial baik dari keluarga, sahabat atau teman, juga dari masyarakat dalam menghadapi perkembangan seksualitas.

Tujuan penelitian ini ialah mengetahui hubungan sosial budaya, respon koping dan dukungan sosial terhadap tingkat kecemasan remaja awal pada perkembangan seksualitas kelas VII di SMPN 276 Jakarta tahun 2018.

\section{Metode}

Penelitian ini yakni penelitian kuantitatif dengan desain deskriptif analitik dengan menggunakan pendekatan cross sectional. Desain studi Cross sectional yakni suatu penelitian dimana mengukur variabel bebas serta variabel terikat yang di kumpulkan dalam waktu yang bersamaan dalam satu sampel populasi. ${ }^{9} \quad$ Alasan menggunakan desain tersebut dalam penelitian ini yakni untuk mengetahui hubungan sosial budaya, respon koping dan dukungan sosial terhadap tingkat kecemasan remaja awal pada perkembangan seksualitas kelas VII di SMPN 276 Jakarta tahun 2018.

Penelitian ini dilakukan pada bulan Januari 2018 di SMPN 276 Jakarta. Populasi dalam penelitian ini ialah siswa/siswi kelas VII di SMPN 276 Jakarta tahun 2018 yang berjumlah 216 orang.

Sampel penelitian ini ialah objek yang diteliti dan dianggap mewakili seluruh populasi. ${ }^{10}$ Bila populasi besar serta peneliti tidak mungkin mempelajari semua yang ada pada populasi, contohnya akibat keterbatasan dana, tenaga dan waktu, maka peneliti bisa memakai sampel yang diambil dari populasi tersebut. Apa yang dipelajari dari sampel, kesimpulannya akan mampu digunakan untuk populasi. Untuk sampel yang didapat dari populasi harus benar-benar representative (mewakili). ${ }^{11}$ Rumus yang digunakan untuk menentukan ukuran sampel yaitu menggunakan rumus Slovin. ${ }^{10}$ Dari hasil perhitungan dan tahap kesalahan 5\% maka peneliti mengambil sampel dari siswa/siswi kelas VII di SMPN 276 Jakarta yaitu sebanyak 140 orang. Teknik pengambilan sampel yaitu teknik probability sampling yaitu pengambilan sampel secara acak dimana setiap subjek dalam populasi mendapat kesempatan yang sama untuk dipilih sebagai anggota sampel. Metode pengambilan sampel menggunakan metode simple random sampling yang merupakan metode yang paling sederhana dengan cara sampel diambil secara acak tanpa memperhatikan tingkatan yang ada pada populasi. ${ }^{12}$ Jenis data yang dipergunakan pada penelitian ini yakni data primer yang berasal dari penyebaran kuesioner yang diisi oleh responden. Kriteria inklusi dan eksklusi 
sampel pada penelitian ini ialah : (1) Kriteria inklusi ialah kriteria atau ciri-ciri yang perlu dipenuhi pada setiap anggota populasi yang dapat diambil sebagai sampel, ${ }^{10}$ pada penelitian ini yakni siswa kelas VII SMPN 276 Jakarta pada tahun 2018, siswa yang hadir saat penyebaran kuesioner dan siswa yang bersedia dan setuju menjadi responden penelitian. (2) Kriteria non inklusi ialah karakteristik yang tidak termasuk dalam penelitian. Pada penelitian ini ialah siswa kelas VIII dan IX SMPN 276 Jakarta. (3) Kriteria Eksklusi ialah menghilangkan atau mengeluarkan subyek yang memenuhi kriteria inklusi dari penelitian karena sebab tertentu, ${ }^{13}$ di dalam penelitian ini yakni siswa kelas VII SMPN 276 Jakarta yang berhalangan hadir ketika penelitian berlangsung.

Variabel yakni sesuatu yang digunakan sebagai ciri, sifat atau ukuran yang dimiliki oleh satuan penelitian mengenai suatu konsep pengertian tertentu. ${ }^{10}$ Variabel bebas ialah variabel yang mempengaruhi atau nilainya menentukan variabel lain. ${ }^{14}$ Variabel bebas pada penelitian ini yakni sosial budaya, respon koping dan dukungan sosial. Variabel terikat ialah variabel yang dipengaruhi nilainya ditentukan oleh variabel lain, dengan kata lain yakni faktor yang diamati dan diukur untuk menentukan ada tidaknya hubungan atau pengaruh dari variabel bebas. ${ }^{14}$ Variabel terikat pada penelitian ini yakni tingkat kecemasan remaja awal pada perkembangan seksualitas.

Instrumen penelitian yang dipakai ialah kuesioner, meliputi pertanyaan terstruktur dan berkaitan dengan variabel yang akan diteliti. Kuesioner yakni beberapa pertanyaan tertulis yang dipakai untuk mendapatkan informasi dari responden dalam hal laporan tentang pribadinya, atau hal-hal yang diketahui. Sebelum kuesioner digunakan, dilakukan uji coba untuk mengetahui validitas dan reliabilitas kuesioner, hasil uji coba digunakan untuk memperbaiki kuesioner tersebut. ${ }^{10}$

Kuesioner yang digunakan dalam penelitian ini yakni kuesioner tertutup dimana sudah terdapat pilihan jawabannya, sehingga responden hanya memilih jawaban yang tersedia. Pengisian kuisioner dengan memberi tanda centang $(\sqrt{ })$ pada jawaban yang dianggap benar. Variabel sosial budaya, respon koping serta dukungan sosial menggunakan skala Likert. Variabel kecemasan menggunakan
Skala HARS yaitu pengukuran kecemasan yang didasarkan pada munculnya symptom pada individu yang mengalami kecemasan. Menurut skala HARS terdapat 14 simptom yang terlihat pada individu yang mengalami kecemasan. Sebelum instrumen atau alat ukur digunakan untuk penelitian maka dilakukan uji coba kuesioner/soal terlebih dahulu yaitu dilakukan uji validitas serta reliabilitas. Uji coba dilakukan pada 20 siswa/siswi SMPN 276 pada bulan November tahun 2017. Instrumen berupa kuesioner berjumlah 5 pertanyaan sosial budaya, 5 pertanyaan respon koping, 20 pertanyaan dukungan sosial serta 14 pertanyaan kecemasan.

Validitas berasal dari kata validity yang berarti sejauh mana ketetapan serta kecermataan suatu alat ukur dalam mengukur suatu data. ${ }^{11}$ Instrument dikatakan valid jika dapat mengungkapkan data dari variable yang diteliti secara tepat. ${ }^{9}$ Uji validitas dilaksanakan kepada 20 responden hasilnya kemudian dikonsultasikan $\mathrm{ke} \mathrm{r}_{\text {tabel }}$ untuk $\mathrm{N}=20$ pada total signifikat $95 \%$ nilai $r_{\text {tabel }} 0,444$ Instrumen dikatakan valid jikan nilai $r_{\text {hitung }}$ untuk seluruh peryataan lebih besar dari pada rtabel. Reabilitas yakni indeks yang memperlihatkan sejauh mana suatu alat pengukuran dapat dipercaya atau dapat diandalkan. Alat ukur yang digunakan harus akurat dan tidak menyebabkan kesalahan dalam suatu pengukuran. Hal ini berarti memperlihatkan sejauh mana hasil pengukuran itu tetap konsisten atau tetap asas (ajeg) bila dilakukan pengkuran 2 kali atau lebih terhadap gejala yang sama, dengan meenggunakan alat ukur yang sama. ${ }^{10}$ Pengujian reabilitas dimulai dengan menguji validitas terlebih dahulu. Jadi jika sebuah pernyataan tidak valid, maka pernyataan tersebut dibuang. Pernyataanpernyataan yang sudah valid kemudian baru secara bersama diukur reabilitasnya. Dalam melakukan perhitungan Alpha, digunakan alat bantu dengan menggunakan model Alpha. Sedangkan pengambilan keputusan reabilitas suatu instrumen dikatakan reable jika Cronbach Alpha lebih dari nilai $\mathrm{r}_{\text {tabel. }}$

Pengolahan data dilakukan setelah pengumpulan data serta data akan diatur melalui program statistic product for social and science (SPSS) versi 18. Analisis yang dilakukan yakni analisis univariat dan analisis bivariat. Analisis univariat dilakukan untuk melihat frekuensi dari variabel dependen dan 
variable independen. Dibuat tabel distribusi frekuensi dari semua sebaran variable yang ada pada penelitian ini. Data yang diproleh akan diperiksa secara univariat, yakni untuk memperlihatkan karakteristik sampel penelitian, dimana kategori jawaban responden ditampilkan dalam bentuk tabel distribusi frekuensi masing-masing variable. ${ }^{15}$ Analisa bivariat yang dilakukan kepada dua variabel yang diduga berhubungan atau berkorelasi. Seluruh analisis bivariat pada penelitian ini menggunakan bantuan perhitungan komputer dengan program statistik SPSS versi 18. Untuk mengetahui hubungan tersebut menggunkan rumus chie-square. Dengan menggunakan drajat kepercayaan $95 \%$ dengan persisi $5 \%$ atau $\alpha=0,05$. Hasil uji stastistik ialah untuk mengetahui apakah keputusan uji H0 ditolak atau H0 diterima (gagal ditolak). Dengan ketentuan apabila $\mathrm{P}$ value $<0,05$ maka $\mathrm{H} 0$ ditolak artinya ada hubungan yang signifikat antara variable independen dan dependen. Jika $\mathrm{P}$ value $>0,05$ maka $\mathrm{H} 0$ diterima, artinya tidak ada hubungan yang signifikat antara variable. ${ }^{10}$

Penelitian ini menggunakan penyajian data dengan narasi (kalimat) atau memberikan keterangan secara tulisan. Pengumpulan data dalam bentuk tertulis mulai dari pengambilan sampel, pelaksanaan pengumpulan data serta sampai hasil analisa yang berupa informasi dari pengumpulan data tersebut. Penelitian ini juga mengunakan penyajian data secara tabular yakni memberikan keterangan berbentuk angka. Jenis yang digunakan pada penelitian ini ialah master tabel, tabel distribusi frekuensi, dan tabel silang. Interpretasi data disajikan dalam bentuk narasi sehingga memudahkan pemahaman kepada hasil penelitian, yaitu diungkapkan bahwa berdasarkan teori yang ada dapat dilihat adanya hubungan sosial budaya, respon koping dan dukungan sosial terhadap tingkat kecemasan remaja awal pada perkembangan seksualitas kelas VII di SMPN 276 Jakarta Tahun 2018.
Hasil

\section{Analisis univariat}

Tabel 1. Distribusi frekuensi tingkat kecemasan, sosial budaya, respon koping dan dukungan sosial remaja awal pada perkembangan seksualitas kelas VII di SMPN 276 Jakarta tahun 2018

\begin{tabular}{|c|c|c|c|}
\hline \multicolumn{2}{|c|}{ Variabel } & (f) & $(\%)$ \\
\hline \multicolumn{4}{|c|}{ Tingkat Kecemasan } \\
\hline \multicolumn{2}{|c|}{ Tidak Ada Kecemasan } & 14 & 10 \\
\hline \multicolumn{2}{|c|}{ Kecemasan Ringan } & 35 & 25 \\
\hline \multicolumn{2}{|c|}{ Kecemasan Sedang } & 50 & 35,7 \\
\hline \multicolumn{2}{|c|}{ Kecemasan Berat } & 38 & 27,1 \\
\hline \multicolumn{2}{|c|}{ Panik/Kecemasan } & 3 & 2,1 \\
\hline \multicolumn{4}{|l|}{ Sangat Berat } \\
\hline \multicolumn{4}{|l|}{ Sosial Budaya } \\
\hline \multicolumn{2}{|l|}{ Buruk } & 80 & 57,1 \\
\hline \multicolumn{2}{|l|}{ Baik } & 60 & 42,9 \\
\hline \multicolumn{4}{|l|}{ Respon Koping } \\
\hline Mekanisme & Koping & 76 & 54,3 \\
\hline \multicolumn{2}{|l|}{ Maladaptif } & 64 & 45,7 \\
\hline \multicolumn{4}{|l|}{ Adaptif } \\
\hline \multicolumn{4}{|l|}{ Dukungan Sosial } \\
\hline Rendah & & 85 & 60,7 \\
\hline Tinggi & & 55 & 39,3 \\
\hline
\end{tabular}

Berdasarkan tabel 1. diketahui bahwa distribusi frekuensi tingkat kecemasan remaja awal pada perkembangan seksualitas kelas VII di SMPN 276 Jakarta dari 140 responden didapatkan sebanyak 50 orang $(35,7 \%)$ memiliki tingkat kecemasan sedang dan sebanyak 3 orang $(2,1 \%)$ memiliki tingkat kecemasan panik/kecemasan sangat berat. Berdasarkan tabel 1. diketahui bahwa distribusi frekuensi sosial budaya terhadap tingkat kecemasan remaja awal pada perkembangan seksualitas kelas VII di SMPN 276 Jakarta dari 140 responden didapatkan sebanyak 80 orang $(57,1 \%)$ memiliki sosial budaya yang buruk dan sebanyak 60 orang $(42,9 \%)$ memiliki sosial budaya yang baik. Berdasarkan tabel 1 . diketahui bahwa distribusi frekuensi respon koping terhadap tingkat kecemasan remaja awal pada perkembangan seksualitas kelas VII 
Tabel 2. Hubungan sosial budaya, respon koping dan dukungan sosial dengan tingkat kecemasan remaja awal pada perkembangan seksualitas kelas VII di SMPN 276 Jakarta tahun 2018

\begin{tabular}{|c|c|c|c|c|c|c|c|c|c|c|c|c|c|}
\hline \multirow{3}{*}{ Variabel } & \multicolumn{10}{|c|}{ Tingkat Kecemasan } & \multirow{2}{*}{\multicolumn{2}{|c|}{ Total }} & \multirow{3}{*}{ P-Value } \\
\hline & \multicolumn{2}{|c|}{$\begin{array}{r}\text { Tidak Ada } \\
\text { Kecemasan }\end{array}$} & \multicolumn{2}{|c|}{$\begin{array}{l}\text { Kecemasan } \\
\text { Ringan }\end{array}$} & \multicolumn{2}{|c|}{$\begin{array}{l}\text { Kecemasan } \\
\text { Sedang }\end{array}$} & \multicolumn{2}{|c|}{$\begin{array}{c}\text { Kecemasan } \\
\text { Berat }\end{array}$} & \multicolumn{2}{|c|}{$\begin{array}{c}\text { Panik/ } \\
\text { Kecemasan } \\
\text { Sangat } \\
\text { Berat }\end{array}$} & & & \\
\hline & $\mathbf{n}$ & $\%$ & n & $\%$ & n & $\%$ & $\mathbf{n}$ & $\%$ & $\mathbf{n}$ & $\%$ & $\mathbf{N}$ & $\%$ & \\
\hline Sosial & & & & & & & & & & & & & 0,009 \\
\hline Budaya & & & & & & & & & & & & & \\
\hline Buruk & 11 & $13,8 \%$ & 24 & $30 \%$ & 30 & $37,5 \%$ & 15 & $18,8 \%$ & 0 & $0 \%$ & 80 & $100 \%$ & \\
\hline Baik & 3 & $5 \%$ & 11 & $18,3 \%$ & 20 & $33,3 \%$ & 23 & $38,3 \%$ & 3 & $5 \%$ & 60 & $100 \%$ & \\
\hline Respon & & & & & & & & & & & & & 0,007 \\
\hline Koping & & & & & & & & & & & & & \\
\hline Maladaptif & 10 & $13,2 \%$ & 25 & $32,9 \%$ & 27 & $35,5 \%$ & 14 & $18,4 \%$ & 0 & $0 \%$ & 80 & $100 \%$ & \\
\hline Adaptif & 4 & $6,3 \%$ & 10 & $15,6 \%$ & 23 & $35,9 \%$ & 24 & $37,5 \%$ & 3 & $4,7 \%$ & 60 & $100 \%$ & \\
\hline Dukungan & & & & & & & & & & & & & 0,014 \\
\hline Sosial & & & & & & & & & & & & & \\
\hline Rendah & 10 & $11,8 \%$ & 16 & $18,8 \%$ & 30 & $35,3 \%$ & 29 & $34,1 \%$ & 0 & $0 \%$ & 80 & $100 \%$ & \\
\hline Tinggi & 4 & $7,3 \%$ & 19 & $34,5 \%$ & 20 & $36,4 \%$ & 9 & $16,4 \%$ & 3 & $5,5 \%$ & 60 & $100 \%$ & \\
\hline
\end{tabular}

di SMPN 276 Jakarta dari 140 responden didapatkan sebanyak 76 orang $(54,3 \%)$ koping adaptif. Berdasarkan tabel 1. diketahui bahwa distribusi frekuensi dukungan sosial terhadap tingkat kecemasan remaja awal pada perkembangan seksualitas kelas VII di SMPN 276 Jakarta dari 140 responden didapatkan sebanyak 85 orang $(60,7 \%)$ memiliki dukungan sosial rendah dan sebanyak 55 orang $(39,3 \%)$ memiliki dukungan sosial tinggi.

\section{Analisis bivariat}

Analisa bivariat yang dilakukan pada dua variabel yang diduga berhubungan atau berkorelasi. Seluruh analisis bivariat pada penelitian ini melalui program statistik SPSS versi 18. Untuk mengetahui hubungan tersebut menggunakan rumus chie-square. Dengan menggunakan drajat kepercayaan $95 \%$ dengan persisi $5 \%$ atau $\alpha=0,05$. Dalam penelitian ini analisis bivariat digunakan untuk melihat hubungan variable bebas sosial budaya, respon koping dan dukungan sosial dengan variabel terikat yaitu tingkat kecemasan remaja awal pada perkembangan seksualitas. Analisis bivariat pada penelitian ini menggunakan bantuan perhitungan komputer dengan program statistik SPSS versi 18. Untuk mengetahui hubungan tersebut menggunakan rumus chie-square. Dengan menggunakan derajat kepercayaan 95\% dengan persisi 5\% atau $\alpha=0,05$. Hasil uji stastistik ialah untuk mengetahui apakah keputusan uji H0 ditolak memiliki respon koping maladaptif dan sebanyak 64 orang $(45,7 \%)$ memiliki respon atau H0 diterima (gagal ditolak). Dengan ketentuan apabila $\mathrm{P}$ value $<0,05$ maka $\mathrm{H} 0$ ditolak artinya ada hubungan yang signifikat antara variable independen dan dependen. Jika $\mathrm{P}$ value $>0,05$ maka $\mathrm{H} 0$ diterima, artinya tidak ada hubungan yang signifikat antara variable. ${ }^{10}$

Berdasarkan tabel 2. hasil analisis hubungan sosial budaya dengan tingkat kecemasan remaja awal pada perkembangan seksualitas diperoleh sebanyak 30 siswa $(37,5 \%)$ memiliki sosial budaya yang buruk dan tingkat kecemasan sedang terhadap perkembangan seksualitas. Hasil uji statistik chi square hubungan sosial budaya dengan tingkat kecemasan remaja awal pada perkembangan seksualitas diperoleh nilai $\mathrm{p}=$ 0,009 artinya p.value $<\alpha(0,05)$, sehingga dapat disimpulkan hipotesis nol (Ho) ditolak artinya ada hubungan yang signifikan antara sosial budaya dengan tingkat kecemasan remaja awal pada perkembangan seksualitas.

Berdasarkan tabel 2. hasil analisis hubungan respon koping dengan tingkat kecemasan remaja awal pada perkembangan seksualitas diperoleh sebanyak 27 siswa $(35,5 \%)$ memiliki respon koping maladaptif dan tingkat kecemasan sedang terhadap perkembangan seksualitas. Hasil uji statistik chi square hubungan respon koping dengan tingkat kecemasan remaja awal pada perkembangan seksualitas diperoleh nilai $\mathrm{p}=$ 0,007 artinya p.value $<\alpha(0,05)$, sehingga 
dapat disimpulkan hipotesis nol (Ho) ditolak artinya ada hubungan yang signifikan antara respon koping dengan tingkat kecemasan remaja awal pada perkembangan seksualitas.

Berdasarkan tabel 2. hasil analisis hubungan dukungan sosial dengan tingkat kecemasan remaja awal pada perkembangan seksualitas diperoleh sebanyak 30 siswa $(35,3 \%)$ memiliki dukungan sosial yang buruk dan tingkat kecemasan sedang terhadap perkembangan seksualitas. Hasil uji statistik chi square hubungan dukungan sosial dengan tingkat kecemasan remaja awal pada perkembangan seksualitas diperoleh nilai $\mathrm{p}=$ 0,014 artinya p.value $<\alpha(0,05)$, sehingga dapat disimpulkan hipotesis nol (Ho) ditolak artinya ada hubungan yang signifikan antara dukungan sosial dengan tingkat kecemasan remaja awal pada perkembangan seksualitas.

\section{Pembahasan}

\section{Tingkat kecemasan pada perkembangan seksualitas}

Ansietas yakni kekhawatiran yang belum jelas serta menyebar yang berhubungan dengan perasaan tidak menentu dan tidak berdaya. Keadaan emosi ini tidak mempunyai objek yang spesifik. Kecemasan pada tiap orang akan berbeda dan bersifat sangat subjektif dan akan dikomunikasikan secara interpersonal. Ansietas atau kecemasan sedikit beda dengan rasa takut, yakni respon seseorang penilaian intelektual pada adanya suatu bahaya. Ansietas ialah respon emosional kepada penilaian sesuatu. Ansietas berat tidak sejalan dengan kehidupan. ${ }^{16}$

Berdasarkan hasil penelitian diketahui bahwa distribusi frekuensi tingkat kecemasan remaja awal pada perkembangan seksualitas kelas VII di SMPN 276 Jakarta dari 140 responden didapatkan sebanyak 50 orang $(35,7 \%)$ memiliki tingkat kecemasan sedang pada perkembangan seksualitas. Tingkat kecemasan pada tiap orang akan berbeda-beda dan bersifat sangat subjektif dan akan dikomunikasikan secara interpersonal sesuai dengan respon seseorang terhadap penilaian intelektual pada adanya suatu bahaya.

\section{Sosial budaya}

Suatu kebiasaan dan tradisi yang diciptakan oleh masyarakat itu sendiri yang dilakukan turun menurun tanpa melalui penalaran apakah yang dilakukan baik atau buruk. Dengan demikian seseorang akan bertambah pengetahuannya walaupun tidak melakukan. Adat istiadat yang berlaku setiap daerah akan berbeda-beda dan mempengaruhi terhadap perilaku seseorang. ${ }^{17}$

Berdasarkan hasil penelitian diketahui bahwa distribusi frekuensi sosial budaya terhadap tingkat kecemasan remaja awal pada perkembangan seksualitas kelas VII di SMPN 276 Jakarta dari 140 responden didapatkan sebanyak 80 orang $(57,1 \%)$ memiliki sosial budaya yang buruk dalam menghadapi perkembangan seksualitas

\section{Respon koping}

Koping yaitu suatu usaha adaptasi seseorang diitujukan pada sumber yang menimbulkan stress yang menyebabkan munculnya emosi-emosi yang tidak menyenangkan. Stress adalah suatu akibat dari proses penilaian yang dilakukan oleh individu, penilaian pada sumber daya yang dimilki oleh seseorang saat menghadapi tuntutan dari lingkungan. ${ }^{18}$

Berdasarkan hasil penelitian diketahui bahwa distribusi frekuensi respon koping terhadap tingkat kecemasan remaja awal pada perkembangan seksualitas kelas VII di SMPN 276 Jakarta dari 140 responden didapatkan sebanyak 76 orang $(54,3 \%)$ memiliki respon koping maladaptif dalam menghadapi perkembangan seksualitas.

\section{Dukungan sosial}

Rook mengungkapkan bahwa dukungan sosial yakni salah satu fungsi dari ikatan sosial, serta ikatan-ikatan sosial tersebut memaparkan tingkat kualitas umum dari hubungan interpersonal. Ikatan dan persahabatan terhadap orang lain diduga sebagai aspek yang membagikan kepuasan secara emosional pada kehidupan individu. Saat individu didukung oleh lingkungan maka segalanya akan terasa 
lebih mudah. Dukungan sosial memperlihatkan pada hubungan interpersonal yang melindungi seseorang pada konsekuensi negatif dari stress. Dukungan sosial yang diterima dapat menghasilkan seseorang merasa tenang, dicintai, timbul rasa percaya diri serta kompeten. ${ }^{19}$

Berdasarkan hasil penelitian diketahui bahwa distribusi frekuensi dukungan sosial terhadap tingkat kecemasan remaja awal pada perkembangan seksualitas kelas VII di SMPN 276 Jakarta dari 140 responden didapatkan sebanyak 85 orang $(60,7 \%)$ memiliki dukungan sosial rendah dalam menghadapi perkembangan seksualitas.

\section{Hubungan sosial budaya dengan tingkat kecemasan remaja awal pada perkembangan seksualitas kelas VII}

Hasil analisis hubungan sosial budaya dengan tingkat kecemasan remaja awal pada perkembangan seksualitas diperoleh sebanyak 30 siswa $(37,5 \%)$ memiliki sosial budaya yang buruk dan tingkat kecemasan sedang terhadap perkembangan seksualitas.

Hasil uji statistik chi square hubungan sosial budaya dengan tingkat kecemasan remaja awal pada perkembangan seksualitas diperoleh nilai $\mathrm{p}=0,009$ artinya $\mathrm{p}$.value $<\alpha$ $(0,05 \%)$, sehingga dapat disimpulkan hipotesis nol (Ho) ditolak artinya ada hubungan yang signifikan antara sosial budaya dengan tingkat kecemasan remaja awal pada perkembangan seksualitas.

Suatu kebiasaan dan tradisi yang diciptakan oleh masyarakat itu sendiri yang dilakukan turun menurun tanpa melalui penalaran apakah yang dilakukan baik atau buruk. Dengan demikian seseorang akan bertambah pengetahuannya walaupun tidak melakukan. Adat istiadat yang berlaku setiap daerah akan berbeda-beda dan mempengaruhi terhadap perilaku seseorang. Sistem sosial budaya yang berlaku di masyarakat dapat mempengaruhi sikap dalam menerima informasi. Budaya terkadang mengekang tingkat pengetahuan seseorang, berbagai kepercayaan ataupun kebiasaan dalam adat terkadang membuat seseorang dilarang dalam mencoba melakukan sesuatu. ${ }^{17}$

Sosial budaya merupakan segala sesuatu yang dihasilkan oleh manusia dengan pemikiran dan budi nuraninya untuk kehidupan bermasyarakat. Atau singkatnya manusia membuat sesuatu berdasar budi dan pikirannya yang diperuntukkan dalam kehidupan bermasyarakat. ${ }^{20}$

Hal ini sesuai dengan penelitian Novi Aprilia Kumala Dewi (2012) mengenai Gambaran Tingkat Pengetahuan Tentang Perkembangan Seksualitas Pada Remaja Awal SMPIT Anugerah Insani Bogor, dimana dijelaskan bahwa berjumlah 86 orang $(91,5 \%)$ memiliki pengetahuan yang rendah mengenai mitos yang ada. Hal ini disebabkan karena remaja tidak mendapatkan informasi yang benar mengenai perkembangan seksualitas yang dialaminya sehingga remaja percaya pada adat istiadat yang berkembang di masyarakat. ${ }^{21}$

Asumsi peneliti sosial budaya memiliki pengaruh penting dalam tingkat kecemasan remaja awal pada perkembangan seksualitas karena sosial budaya yang berlaku di masyarakat dapat mempengaruhi sikap dalam menerima informasi terlebih lagi dalam hal ini mengenai perkembangan seksualitas pada remaja. Jika informasi yang didapatkan tidak sesuai yang diharapkan maka timbul kecemasan pada remaja dalam menghadapi perkembangan seksualitasnya.

\section{Hubungan respon koping dengan tingkat kecemasan remaja awal pada perkembangan seksualitas kelas VII}

Hasil analisis hubungan respon koping dengan tingkat kecemasan remaja awal pada perkembangan seksualitas diperoleh sebanyak 27 siswa $(35,5 \%)$ memiliki respon koping maladaptif dan tingkat kecemasan sedang terhadap perkembangan seksualitas.

Hasil uji statistik chi square hubungan respon koping dengan tingkat kecemasan remaja awal pada perkembangan seksualitas diperoleh nilai $\mathrm{p}=0,007$ artinya $\mathrm{p}$.value $<\alpha$ $(0,05 \%)$, sehingga dapat disimpulkan hipotesis nol (Ho) ditolak artinya ada hubungan yang signifikan antara respon koping dengan tingkat kecemasan remaja awal pada perkembangan seksualitas.

Mekanisme koping ialah cara mencari solusi atau suatu pemecahan masalah. Individu dapat menangani stress serta kecemasan dengan menggunakan sumber koping dari lingkungan baik dari sosial, intrapersonal juga interpersonal. Sumber itu dapat berupa aset ekonomi, kemampuan memecahkan masalah, 
dukungan sosial, serta keyakinan budaya. Dengan sumber tersebut seseorang bisa mengambil strategi koping yang efektif. ${ }^{18}$

Apabila individu sedang dalam situasi dianggap mengancam menghadapi kecemasan ia dapat mencoba menetralisasi, mengingkari atau meniadakan kecemasan pada mengembangkan pola koping. Pada kecemasan ringan, mekanisme koping yang biasanya digunakan yaitu menangis, tidur, makan, tertawa, berkhayal, memaki, merokok, olahraga, mengurangi kontak mata dengan orang lain, membatasi diri dengan orang lain. ${ }^{18}$

Hal ini sejalan dengan penelitian Gannis Eka Pramita Sari (2010) mengenai Perbedaan Ketidakpuasan Terhadap Bentuk Tubuh Ditinjau Dari Strategi Koping Pada Remaja Wanita di SMA Negeri 2 Ngawi dimana didapatkan hasil adanya hubungan perbedaan mengenai ketidakpuasan bentuk tubuh yang signifikan antara kelompok strategi koping dengan ketidakpuasan bentuk tubuh pada remaja. Hal ini dapat dilihat dari nilai $\mathrm{p}=$ $0,019$ ( $p$ value $<0,05){ }^{22}$ Ketidakpuasaan bentuk tubuh disini merupakan salah satu bentuk perkembangan seksualitas yang dialami pada remaja.

Asumsi peneliti respon koping memiliki peranan penting dalam tingkat kecemasan remaja awal pada perkembangan seksualitas karena individu dapat menangani stress serta kecemasan dengan menggunakan sumber koping dari lingkungan baik dari sosial, intrapersonal juga interpersonal. Jika individu sedang dalam situasi dianggap mengancam menghadapi kecemasan ia dapat mencoba menetralisasi, mengingkari atau meniadakan kecemasan pada mengembangkan pola koping. Maka dari itu respon koping mempunyai kaitan yang erat dengan tingkat kecemasan.

\section{Hubungan dukungan sosial dengan tingkat kecemasan remaja awal pada perkembangan seksualitas kelas VII}

Hasil analisis hubungan dukungan sosial dengan tingkat kecemasan remaja awal pada perkembangan seksualitas diperoleh sebanyak 30 siswa $(35,3 \%)$ memiliki sosial budaya yang buruk dan tingkat kecemasan sedang terhadap perkembangan seksualitas.

Hasil uji statistik chi square hubungan dukungan sosial dengan tingkat kecemasan remaja awal pada perkembangan seksualitas diperoleh nilai $\mathrm{p}=0,014$ artinya $\mathrm{p}$.value $<\alpha$ $(0,05 \%)$, sehingga dapat disimpulkan hipotesis nol (Ho) ditolak artinya ada hubungan yang signifikan antara dukungan sosial dengan tingkat kecemasan remaja awal pada perkembangan seksualitas.

Dukungan sosial memperlihatkan pada hubungan interpersonal yang melindungi seseorang pada konsekuensi negatif dari stress. Dukungan sosial yang diterima dapat menghasilkan seseorang merasa tenang, dicintai, timbul rasa percaya diri serta kompeten. ${ }^{19}$

Dukungan sosial memberikan kenyamanan fisik serta psikologis terhadap seseorang dapat dilihat bagaimana dukungan sosial mempengaruhi kejadian dan efek dari kondisi kecemasan. Secara teoritis dukungan sosial mampu menurunkan hadirnya kejadian yang dapat mengakibatkan kecemasan. Apabila kejadian itu timbul, interaksi dengan orang lain bisa memodifikasi atau mengubah persepsi individu pada kejadian tersebut serta akan mengurangi potensi munculnya kecemasan. Dukungan sosial pun bisa mengubah hubungan antar respon seseorang kepada kejadian yang bisa menimbulkan kecemasan. Kecemasan itu sendiri mempengaruhi strategi untuk mengatasi kecemasan dengan begitu memodifikasi hubungan antara kejadian yang mengakibatkan kecemasan serta efeknya. Pada derajat dimana kejadian yang menghasilkan kecemasan mengganggu kepercayaan diri serta dukungan sosial dapat memodifikasi efek itu. ${ }^{23}$

Hal ini sejalan dengan penelitian Yustisiana Hidayati (2012) mengenai Perbedaan Tingkat Kecemasan Mengalami Pubertas Pada Remaja Awal Ditinjau Dari Tingkat Dukungan Sosial, dimana didapatkan hasil adanya hubungan perbedaan mengenai kecemasan mengalami pubertas dini pada remaja awal yang memiliki tingkat dukungan sosial rendah dan tingkat dukungan sosial tinggi. Hal ini dapat dilihat dari nilai $\mathrm{p}=0,002$ $(p$ value $<0,05){ }^{24}$

Asumsi peneliti dukungan sosial memiliki peranan penting dalam tingkat kecemasan remaja awal pada perkembangan seksualitas karena dukungan sosial pun bisa mengubah hubungan antar respon seseorang kepada kejadian yang bisa menimbulkan kecemasan. 
Sehingga dukungan sosial dan kecemasan saling berkaitan.

\section{Kesimpulan}

Setelah dilakukan penelitian dan pembahasan yang telah diuraikan pada bab sebelumnya mengenai Hubungan Sosial Budaya, Respon Koping dan Dukungan Sosial Terhadap Tingkat Kecemasan Remaja Awal pada Perkembangan Seksualitas Kelas VII di SMPN 276 Jakarta Tahun 2018 maka hasil yang dapat disimpulkan adalah hasil analisis univariat bahwa sebagian besar responden memiliki kecemasan sedang sebanyak 50 orang $(35,7 \%)$, sosial budaya buruk sebanyak 80 orang $(57,1 \%)$, respon koping maladaptif sebanyak 76 orang $(54,3 \%)$ dan dukungan sosial rendah sebanyak 85 orang $(60,7 \%)$. Hasil analisis bivariat menggunakan uji $C h i$ Square dengan $\alpha 0,05$ diperoleh sosial budaya p-value 0,009, respon koping p-value 0,007, dukungan sosial p-value 0,014 dapat disimpulkan bahwa ada hubungan Sosial Budaya, Respon Koping dan Dukungan Sosial Terhadap Tingkat Kecemasan Remaja Awal pada Perkembangan Seksualitas Kelas VII di SMPN 276 Jakarta Tahun 2018.

\section{Saran}

Bagi responden diharapkan untuk memperbanyak mencari dan memahami informasi dapat melalui kegiatan konseling ataupun penyuluhan tentang perkembangan seksualitas pada remaja sehingga siap dalam menghadapi perkembangan seksualitas yang sedang dialami.

Bagi SMPN 276 Jakarta diharapkan dapat dijadikan bahan pertimbangan kebijakan dalam pemberian informasi dan mengadakan kegiatan konseling serta penyuluhan untuk kedepannya mengenai perkembangan seksualitas remaja.

Bagi peneliti selanjutnya Diharapkan penelitian ini dapat dijadikan dasar atau bahan masukan untuk melakukan penelitian selanjutnya dalam hal yang berkaitan

\section{Daftar pustaka}

1. World Health Organization (WHO) ; 2015.

2. InfoDATIN. Situasi Kesehatan Reproduksi Remaja Indonesia. Jakarta : Kemenkes RI; 2016.

3. BKKBN; 2010.

4. BKKBN; 2013.

5. Rohan dan Siyoto. Buku Ajar Kesehatan Reproduksi. Yogyakarta: Nuha Medika; 2013.
6. Potter dan Perry. Fundamental keperawatan buku 3. Edisi 7. Jakarta : Salemba Medika; 2010.

7. Agustiani H. Psikologi Perkembangan : Pendekatan Ekologi Kaitannya dengan Konsep Diri dan Penyesuaian Diri pada Remaja. Bandung : Refika Aditama; 2009.

8. Siregar C. Tingkat kecemasan pada santri pondok pesantren. Jakarta : Jurnal Psikologi Vol 01 No 01; 2013.

9. Sugiyono. Statistik Untuk Penelitian. Bandung : Alfabeta; 2010.

10. Notoatmodjo S. Pendidikan dan Perilaku Kesehatan. Jakarta : Rineka Cipta; 2010.

11. Taniredja dan Mustafidah. penelitian kuantitatif (sebuah pengantar). Jakarta: alfabeta; 2012.

12. Setiawan dan Saryono. Metodologi Penelitian Kebidanan. Yogyakarta; Nuha Medika; 2011.

13. Darmadi H. Metode Penelitian Pendidikan dan Sosial. Bandung : Alfabeta; 2013.

14. Nursalam. Manajemen Keperawatan. Jakarta : Salemba Medika; 2013.

15. Prasetiyo J. Evakuasi dan Remediasi Belajar.Jakarta : Trans Info Media; 2013.

16. Stuart G. W. Buku Saku Keperawatan Jiwa (Edisi 5). Jakarta :EGC; 2013.

17. Wawan dan Dewi. Teori dan Pengukuran Pengetahuan Sikap dan Perilaku Manusia. Jakarta : Pustaka Sinar Harapan; 2010.

18. Lestari T. Kumpulan Teori Untuk Kajian Pustaka Penelitian Kesehatan. Yogyakarta: Nuha Medika; 2015.

19. Kumalasari. Hubungan Dukungan Sosial dengan Penyesuaian Diri Remaja di Panti Asuhan. Jurnal Psikologi Vol-1. No-1; 2012.

20. Setiadi E. Ilmu Sosial dan Budaya Dasar. Bandung: Kencan Perdana Media Group; 2012.

21. Dewi K. Gambaran Tingkat Pengetahuan Tentang Perkembangan Seksualitas Pada Remaja Awal SMPIT Anugerah Insani Bogor. Jurnal Psikologi Universitas Indonesia Vol-1. No-1; 2012.

22. Sari G. Perbedaan Ketidakpuasan Terhadap Bentuk Tubuh Ditinjau Dari Strategi Koping Pada Remaja Wanita di SMA Negeri 2 Ngawi. Jurnal Psikologi Universitas Sebelas Maret Vol-1. No-1; 2010.

23. Hillier F, Gerald J dan Lieberman. Introduction to Operations Research - ninth edition. United States : The McGraw-Hill Companies; 2010.

24. Hidayati Y dan Mastuti E. Perbedaan Tingkat Kecemasan Mengalami Pubertas Dini Pada Remaja Awal Ditinjau Dari Tingkat Dukungan Sosial. Jurnal Psikologi Universitas Airlangga Vol-1. No-1; 2012. 